\title{
Effect of Exchange Rate Returns on Equity Prices: Evidence from South Africa and Nigeria
}

\author{
Jibrin Daggash $^{1} \&$ Terfa W. Abraham ${ }^{2}$ \\ ${ }^{1}$ School of Political, Economic and Policy Sciences (EPPS), University of Texas at Dallas, United States \\ ${ }^{2}$ Public Finance/ Macroeconomic Research Unit, National Institute for Legislative Studies (NILS), Nigeria \\ Correspondence: Dr Terfa W. Abraham, Public Finance/ Macroeconomic Research Unit, National Institute for \\ Legislative Studies (NILS), No. 1 River Niger Street, Maitama, Abuja, Nigeria. Tel: 234-806-209-1306. E-mail: \\ Lorenzcurve@yahoo.com
}

Received: August 30, 2017

Accepted: September 21, 2017

Online Published: October 1, 2017

doi:10.5539/ijef.v9n11p35

URL: https://doi.org/10.5539/ijef.v9n11p35

\begin{abstract}
This paper examines the exchange rate returns of the Rand (relative to the US dollar) and the Naira (relative to the US dollar) for the presence of volatility. It also examines the effect of the exchange rate returns on the performance of their respective stock market. While it was found that the returns of the South African Rand was volatile, the Nigerian naira was not. Estimating the effect of exchange rate returns and crude oil price on the stock market indices of both countries showed that exchange rate return have a positive effect on the performance of the Nigerian stock exchange thus, confirming the stock flow hypothesis for Nigeria and refuting same for South Africa. Although the VAR granger causality identifies short run fluctuation of the naira as a significant factor affecting the performance of the Nigerian stock exchange in the short run, the Johannesburg stock exchange was found to be mostly affected by short run changes in the Rand and the UK FTSE 100. The paper concludes that policies aimed at stabilizing exchange rate and encouraing more non-oil stocks to be quoted in the Nigerian stock exchange will important. For the Johanesburg stock exchange, raising the listing requirement for firms quoted in the UK FTSE 100 and also seeking listing or already listed in the JSE will be a plausible idea. For both countries, however, curtailing swings in their exchange rate returns would help attract new investments and sustain existing ones hence, helping to spur growth.
\end{abstract}

Keywords: exchange rate returns, stock market, volatility models, VAR Granger causality

\section{Introduction}

Achieving exchange rate stability is a central concern of apex banks in developing and emerging economies. Although several studies have examined the direct effect of exchange rate volatility on various aspect of the economy, doing same using exchange rate returns, have been argued to provide further evidence that could be useful to inform exchange rate management policies. One aspect of the economy for which exchange rate returns manifest such impact is on the country's stock market. While several studies (e.g. Agrawal, Srivastav, \& Srivastava, 2010; Mlambo, Maredza, \& Sibanda, 2013; Abraham, 2016; Sichoongwe, 2016; and Gatawa \& Mahmud, 2017) have examined the effect of exchange rate fluctuation on the performance of stock markets in developing and emerging economies, investigating the effect of exchange rate returns on the performance of emerging stock markets in Africa, could provide further insight on the need to commit to prudent exchange rate management regimes.

Until this paper, recent discourse on exchange rate management in Nigeria have focused on whether or not the policy direction of the CBN to devalue or not to devalue, to float or not to float the exchange rate, will be beneficial to the Nigerian economy or not. Such a perspective, turns the attention of analyst towards examining the direct effect of exchange rate on the economy hence, failing to explore issues around exchange rate volatility and providing insight on the need to keep watch on the effect of exchange rate returns on the economy as well. Like Nigeria, South Africa's plunge into a recession in recent times and the role of its exchange rate in that process offers another motivation for this paper. Although contraction in growth in South Africa's construction, manufacturing and transport sectors, were the earlier sign of South Africa's slip into a recession, the confidence needed to boost investment in the economy was quickly eroded due to uncertainties that affected the value of the Rand thus, failing to boost investment decisions. This gave room for fluctuation in the returns of commodity 
prices to affect the performance of investments in the country's stock market. While the downgrade in its credit risk rating to a sub-investment grade also played a key role in the country's slide into recession, a major pass-through of such rating is the South African Rand. Providing empirical evidence on how exchange rate returns affect the South African Stock Exchange would therefore be critical to help inform its apex bank on the need to remain committed to achieving healthy exchange rate.

According to Ozhan, Atiyas, and Keyman (2016), financial markets play a significant role during periods of economic crisis as a transmitter of shocks to the real economy. Curtailing decline in asset prices by addressing credit issues and loss of investors' confidence, are arguably, issues that require the attention of monetary authorities. Although conventional monetary policy thinking requires that devaluing a country's currency in such times, helps to attract inflow of foreign investors, recent experiences in Nigeria showed that devaluing the naira against the US dollar, did not yield the desired result of attracting foreign investors. The experience in Japan offers another evidence for examining the effect of exchange rate returns on stock market performance. According to Kuroda (2014), at the start of the 1990s, the bubble in the Japanese economy came to an end. During this period, though worsening economic conditions led to increased nonperforming assets and declining prices, the appreciation of the yen helped in giving the Japanese economy a facelift. Evidence from Kuroda (2014) suggests that exchange rate management which aimed at keeping the Yen stable, contributed in boosting confidence in Japanese investments as result, playing a great role in attracting new investments and sustaining existing ones. While studies have examined the nexus between exchange rate and the stock market, using exchange rate returns rather than fluctuation, would provide further insight to inform policy makers on the need to strengthen exchange rate management policies. For instance, Abraham (2016) examined the effect of crude oil price movement on the Nigerian stock market and the role of exchange rate as a plausible countercyclical policy tool. Although the paper found that devaluation of the naira could be effective in cushioning the effect of crude oil price decline on the stock market, results from the granger causality test, revealed that doing so may not be potent as expected. Similarly, Gatawa and Mahmud (2017), analyzed the short and long-run impacts of exchange rate fluctuations on agricultural exports volume in Nigeria. Employing Auto-regressive distributed lag model and Generalised Autoregressive Conditional Heteroskedascity (GARCH) model to estimate the volatility of exchange rates, they found that exchange rate and agricultural loans have positive impact on agricultural export volumes. The result for long run relationship however, showed that the effect of exchange rate on agricultural exports cannot be sustained in the long run. Among other things, they recommended that stabilizing the exchange rate, would help improve agricultural exports and also attract investments to the sector.

Empirical evidence from the Zambian economy, presents further reasons to examine the issue of exchange rate returns on stock market performance. Sichoongwe (2016) examined the effect of exchange rate volatility on the Lusaka stock market using time series data from 2000 to 2015 . GARCH $(1,1)$ model was used to investigate the relationship between exchange rate volatility and stock market returns. A negative relationship was found between exchange rate volatility and stock market returns. The policy deduction was that, achieving exchange rate stability is crucial to attract foreign portfolio investment as well as to sustain existing businesses. Agrawal et al. (2010) investigated the relationship between Nifty returns and Indian rupee (relative to the US dollar). They also investigated the impact of both series on each other using daily closing indices from October, 2007 to March, 2009. They found that the Nifty returns and Indian rupee have a negative correlation. Causal analysis also revealed a unidirectional relationship running from the Nifty returns to exchange rates. The implication is that exchange rate fluctuations does not have a direct effect on stock market returns, rather it is stock market returns that affects exchange rate. Mlambo et al (2013) examined the effect of currency volatility on the Johannesburg Stock Exchange using GARCH $(1,1)$ model for South Africa based on monthly data from 2000-2010. Although they found a very weak relationship between currency volatility and the stock market, it was interesting to also see that US interest rates had a positive impact on the performance of the Johannesburg stock exchange. They concluded that since the South African stock market does not have much exposure to the negative effects of currency volatility, the South African government can use exchange rate as a policy tool to attract foreign portfolio investment. Furthermore, the weak relationship between currency volatility and the stock market suggests that the JSE could be a safe haven for foreign investors as volatility in the market could be minimized hence, curtailing negative spillover effect.

Using a multivariate GARCH in-mean approach, Caporale, Ali, and Spagnolo (2015) examined the effect of exchange rate uncertainty and international portfolio flows for the euro area, Japan, Sweden and the UK from 1988 to 2011. Their finding revealed that exchange rate uncertainty induces a home bias and causes investors to reduce their financial activities in order to maximize returns and minimize exposure to uncertainty. They found that this effect is stronger in the UK, the euro area and Sweden compared to Canada, Australia and Japan. 
Overall, they argued that exchange rate or credit controls can be used to improve the flow of investment particularly in countries where high level of uncertainty affects economic and financial system stability. Premised on the above argument, the aim of this paper therefore is to examine the exchange rate returns of South Africa and Nigeria (relative to the US dollar) for the presence of volatility and also to estimate the effect of the exchange rate returns on the stock market all share indices of both countries. Controlling for their exposure to other financial markets, the paper also estimates how short term changes in the stock market and exchange rate of advanced economies, influence the performance of their counterparts in Nigeria and South Africa.

\section{Literature Review}

The literature documents two theories explaining the relationship between exchange rate and stock market returns: (1) the goods market (or flow oriented) hypothesis (see Dornbusch \& Fischer, 1980); and (2) Portfolio Balance (or the stock oriented) approach (see Branson, 1983). According to the flow oriented approach, movement of a country's exchange rate, leads to movement in asset prices. Hence, any change in a country's exchange rate significantly affects its trade balance and current account, which in turn impacts on the real sector. In order to provide an explanation from a macroeconomic perspective, Zhang (2016) argued that since stock prices can be defined as the present value of a company's expected future cash flows, the Efficient Market Hypothesis postulated by Malkiel and Fama (1970), serves as a variant of the flow oriented hypothesis. According to the Efficient Market Hypothesis, information that impacts on a firm's performance and future cash flow, should be reflected in the firm's stock price if the market is efficient. As a result, stock prices would adjust to general economic conditions and outlook thus, suggesting that there is causal relationship between exchange rate and stock returns. Zhang (2016) provided an example for illustrative purpose.

According to Zhang (2016), in an export dominated economy, a depreciation of home currency will stimulate foreign demand for domestic goods, thus increasing the exports of that country. As a result, the stock prices of firms in that country will increase due to the economic boom. Notable contributions explaining flow oriented hypothesis is also provided by Adjasi and Biekpe (2005). They argued that since exchange rate equates demand and supply for assets prices (bonds and stocks), currency fluctuations may therefore influence movement in stock prices. More so, since a decline in the value of the exchange rate will cause goods and services in the international market to be expensive, it leads to a decline in export. In turn such a decline affects the competitiveness of the firm both at the international and domestic market. Conversely, when the home currency appreciates, domestic firms suffers from the decrease in foreign demand, which leads to a decrease in their profits, as would prices of their stocks. For an import dominated economy, the relationship between exchange rate and firms' stock prices are the opposite as a depreciation of home currency makes foreign inputs more expensive, which increases production costs of firms using foreign inputs. The increase in production costs eventually leads to a reduction in the domestic firms' outputs and profits, which in turn have a negative influence on their stock prices. Appreciation of the country's currency will therefore lead to an increase in the profits of domestic firms, thus increasing their stock prices. In this regard, exchange rate movements can therefore have a positive or negative effect on stock prices depending on whether or not the economy is export or import dominated.

The portfolio balance approach, articulated in Branson (1983), postulates that oscillation of stock prices affects a country's exchange rate through foreign capital outflows and inflows. As such, exchange rate is treated the same way as goods and services that are determined by market forces. In this regard, a boom in domestic stock market will attract foreign investors, which in turn increases the demand for home currency, and eventually lead to capital inflows and an appreciation of home currency (see Zhang, 2016). Howbeit, a decrease in stock return will discourage foreign investors, thus decreasing the demand for home currency, and leading to capital outflows and depreciation of home currency (see Zhang, 2016). Other authors that have contributed to the Stock Oriented hypothesis include Gavin (1989). Using the demand for money theory, Gavin (1989) argued that a decline in stock prices leads to a reduction in the wealth of a country which in turn leads to a decrease in the demand for money, causes capital outflows to fall and leads to currency depreciation. The Stock balance approach therefore postulates that there is a negative relationship between stock prices and exchange rates. In a nutshell, while the flow-oriented hypothesis postulates that exchange rate movements leads to changes in stock prices (see Dornbusch \& Fischer, 1980), the stock orientated model suggests that changes in stock prices leads to changes in exchange rate (see Branson, 1983).

Another theory that provides a framework for modelling exchange rate risk and asset prices is the Capital Asset Pricing Model. Premised on the early foundations provided by Sharpe (1964) and Lintner (1965) and advanced by Grubel (1968), the CAPM builds on the model of portfolio choice developed by Harry Markowitz (1959). According to Fama and French (2004), the Markowitz's model assumes that investors are risk averse hence, only 
worry about the mean and variance of their one-period investment return when choosing among portfolios. As a result, investor's choice of portfolios is influenced by the need to minimize the variance of portfolio return, given expected return, or to maximize expected return, given variance. This is why the Markowitz approach is often called a "mean-variance model. While the portfolio model provides an algebraic condition on asset weights in mean-variance-efficient portfolios, the CAPM turns this algebraic statement into a testable prediction about the relation between risk and expected return by identifying a portfolio that must be efficient if asset prices are to clear the market of all assets (see Fama \& French, 2004).

By way of advancement, Sharpe (1964) and Lintner (1965) introduced two assumptions to the Markowitz model in order to identify a portfolio that meets the mean-variance-efficient condition: Complete agreement and, borrowing/lending at a risk-free-rate. The assumption of complete agreement holds that given market clearing asset prices, investors agree on the joint distribution of asset returns upon which the returns used to test the model are drawn. The second assumption is that there is borrowing and lending at a risk-free rate, which is the same for all investors and does not depend on the amount borrowed or lent. The CAPM therefore postulates that the market portfolio is mean-variance-efficient that is, the differences in expected return across securities and portfolios are entirely explained by differences in market information. As a result, other variables should add nothing to the explanation of expected return. This informs why the CAPM is considered a two parameter, single period model focusing on the expected return of an asset and the asset's riskiness. It also measures risk as the variance of the asset's rate of return over time measured by ex-post data. According to Thomson, Şahin, and Reddy (2013), the advantage from using a single-factor model is that it does not treat currency risks as carrying different weight from investment risks. Thus, regardless of its source, risk is measured as variance and weighted accordingly.

Daily stock prices are affected by several factors. However, as noted by Kim (2003), increase in world trade and capital movements have made exchange rate an important determinant of business profitability and equity prices. The importance of the effect of exchange rate returns on stock market performance is emphasized because of its link as a transmission mechanism from money market to the capital market hence, helping to retain the value of investment in the financial market. Upon such considerations, the relationship between stock returns and foreign exchange rates is a critical investment consideration by investors (see Joseph, 2002; and Benita \& Lauterbach, 2004). According to Papaioannou (2006), changes in exchange rates result in an immediate change in value of the foreign operations of a multinational company, as well as a continuing change in the profit of its foreign operations thereby, reflecting in its successive income statements. Others have also pointed out that domestic firms could also be affected by changes in exchange rates especially when they import a part of their inputs and export their outputs (see Phylaktis \& Ravazzolo, 2005; Mishra, Swain, \& Malhotra, 2007). Thus, as Nieh and Lee, (2001) and Stavárek (2005) argued, understanding the relationship between exchange rate and stock market will assist domestic and international investors to hedge and diversify their portfolio.

A number of studies have examined the relationship between stock prices and exchange rates (e.g. Papaioannou, 2006; Agrawal et al., 2010; Mlambo et al., 2013; Caporale et al., 2015; Abraham, 2016; Sichoongwe, 2016; Ozhan et al., 2016; Sichoongwe, 2016; Gatawa \& Mahmud, 2017; and Gatawa \& Mahmud, 2017). However, little information is available from these studies on the effect of exchange rate returns and its volatility on the stock market. More so, these studies show mixed evidence on the relationship between exchange rate and the stock market. Providing further evidence for country specific cases will therefore be a useful contribution to the literature hence, the need for this paper.

\section{Method}

The focus of this paper is on the effect of exchange rate returns on the stock market indices in Nigeria and South Africa. To achieve this purpose, 5-day weekly data from January 2013 to December 2016, were obtained from Bloomberg, the Central Bank of Nigeria (CBN) and the Nigerian Stock Exchange (NSE). Daily stock returns was defined as $R\left(Z_{t}\right)=100 * \mathrm{DLOG}\left(Z_{t}\right)$; where $R\left(Z_{t}\right)$ is the stock return for a country $\mathrm{Z}$ at time $t$, and DLOG $\left(Z_{t}\right)$ is the difference of the logarithm of country $\mathrm{Z}$ at time $t$. To examine the series for the presence of unit root and determine the order of integration, the Augmented Dickey Fuller test was employed. The test statistics is specified as follows:

$$
\Delta y_{t}=\alpha_{1} \mathrm{y}_{\mathrm{t}-1}+\sum_{i=1}^{n} \gamma_{i} \Delta y_{t-i}+\mu_{t}
$$

Where $\mu_{t}$ is a white noise error term and $\Delta y_{t-1}=\mathrm{y}_{\mathrm{t}-1}-\mathrm{y}_{\mathrm{t}-2}$,

Following Engle (1982), the ARCH/GARCH is used to estimate the exchange rate volatility for South Africa and Nigeria. The mean equation describes how the dependent variable $\left(y_{t}\right)$ varies over time, while the variance equation models autocorrelation in volatility by allowing the conditional variance of the error term $\left(\sigma_{t}^{2}\right)$ to 
depend on the immediately past values of the squared error. The mean and variance equation for an $\mathrm{ARCH}(\mathrm{q})$ model is specified below:

$$
\begin{aligned}
& y_{t}=\beta_{1}+\beta_{2} x_{2 t}+\beta_{3} x_{3 t}+\beta_{4} x_{4 t}+\mu_{t} \quad \mu_{t} \sim \mathrm{N}\left(0, \sigma_{t}^{2}\right) \\
& \sigma_{t}^{2}=\beta_{0}+\sum_{i=1}^{q} \beta_{i} \mu_{t-i}^{2}
\end{aligned}
$$

Where $\mu_{t}$ is the error generated at time $t$, and $\beta_{0}>0 ; \beta_{i} \geq 0 ; \forall i=1, \ldots, \mathrm{q}$

Introduced by Bollerslev (1986), the Generalized ARCH (GARCH) model is used resolve high ARCH orders. As such, the GARCH reduces the number of estimated parameters from an infinite number to just a few. The conditional variance for $\mathrm{GARCH}(\mathrm{p}, \mathrm{q})$ model is expressed as:

$$
\sigma_{t}^{2}=\beta_{0}+\sum_{i=1}^{q} \beta_{i} \mu_{t-i}^{2}+\sum_{j=1}^{p} \alpha_{j} \sigma_{t-j}^{2}
$$

Where $\beta_{0}>0 ; \beta_{i} \geq 0 ; \quad i=1, \ldots, \mathrm{q} ; \quad j=1, \ldots, \mathrm{p}$

$\sigma_{t}^{2}$ is the conditional variance, $\mathrm{q}$ is the order of the ARCH terms $\mu^{2}, \mathrm{p}$ is the order of the GARCH terms $\sigma^{2}, \mu_{t}^{2}$ is the disturbance term and $\beta_{0}$ is the constant term.

The ARCH term which is the lag of the squared residual informs us if volatility from previous period affects volatility in current period. The GARCH parameter is the forecasted variance from the previous period. The persistence of $\sigma_{t}^{2}$ is captured by $\beta_{i}+\alpha_{i}$ and the three parameters $\beta_{0}, \beta_{i}$ and $\alpha_{i}$ are non-negative and covariance stationarity requires that $\beta_{i}+\alpha_{i}<1$. The sum of the ARCH and GARCH term give information about persistent of volatility shocks. A sum of one would lead to the shock to die slowly and a sum less than unity, the shocks would die out slowly.

There are several GARCH specifications for modeling the conditional variance, of a variable. This include the asymmetric TGARCH proposed by Zakoian (1994), EGARCH proposed by Nelson (1991) and PARCH proposed by Ding, Granger, and Engle (1993). In order to measure the impact of currency volatility as well as their returns on the stock markets in South Africa and Nigeria, the explanatory variables that are included in the model are: the exchange rate and crude oil price. The model is expressed as:

$$
D L S M=\beta_{0}+\beta_{1} D L E R_{t}+\beta_{2} D L C R O_{t}+\mu_{t}
$$

Where DLSM is the first difference of the log of stock market; $\beta_{0}$ is the intercept, $E R_{t}$ exchange rate at time t, $C R O_{t}$ is crude oil price at time $\mathrm{t}$, and $\mu_{t}$ is a white noise error term.

To estimate the direction of causality between the stock market performance and exchange rate in Nigeria and South Africa, VAR Granger causality model is also employed. To control for external exposure in the VAR Granger model, data for the US stock market (the Dow Jones), UK FTSE 100, and Japanese NIKKEI 225, as well as the exchange rate of the UK pounds and Japanese Yen (relative to the US dollar), were introduced in the vector granger model. Following Zhang (2016), the VAR granger causality model for non-stationary series is specified in a vector error correction model (VECM) approach as presented below:

$$
\begin{array}{r}
\Delta Y_{t}=\alpha_{0}+\sum_{i=1}^{k} \beta_{i} \Delta Y_{t-i}+\sum_{j=1}^{q} \gamma_{j} \Delta X_{t-j}+\lambda_{1} E C T_{t-1}+\varepsilon_{t} \\
\Delta X_{t}=\alpha_{1}+\sum_{i=1}^{k} \theta_{i} \Delta Y_{t-i}+\sum_{j=1}^{q} \eta_{j} \Delta X_{t-j}+\lambda_{2} E C T_{t-1}+\mu_{t}
\end{array}
$$

Where $Y_{t}$ and $X_{t}$ depend on past information and ECT is the error correction term that allows for the estimation of VAR granger causality for a non-stationary series.

\section{Results}

This section provides result from estimation and interprets them to fulfill the objective of the paper. First, the descriptive statistics of the exchange rates and their trend are discussed. The variables (exchange rate, crude oil price and stock market indices) are also tested for the presence of volatility using volatility model. Table 1 reports the summary statistics of returns of all the exchange rates and the exchange rate data at levels. The South African Rand has the least standard deviation implying that it has a minimum spread about its mean, which is reflective of a stable and predictable exchange rate environment. On the other hand, the Nigerian naira has the highest standard deviation implying that it has a greater spread around its mean. 
Table 1. Descriptive statistics - summary statistics of return series (exchange rate)

\begin{tabular}{lcccccccc}
\hline Variables & Mean & Maximum & Minimum & Std Dev & Skewness & Kurtosis & Jarque-Bera & p-value \\
\hline Naira & 0.1456 & 87.84 & -17.000 & 3.07646 & 23.559 & 655.338 & 18322600 & 0.00 \\
Rand & 0.0053 & 0.7996 & -0.9351 & 0.1338 & 0.15504 & 10.093 & 2159.685 & 0.00 \\
\hline \multicolumn{7}{l}{ Descriptive Statistics } & S Summary Statistics of Exchange Rate (Level Data) \\
Naira & 188.09 & 325.00 & 155.700 & 46.29 & 1.687 & 4.777 & 623.35 & 0.00 \\
Rand & 11.966 & 16.91 & 8.355 & 2.0647 & 0.4180 & 2.0503 & 68.65 & 0.00 \\
\hline
\end{tabular}

Figure 1 displays the line graph of exchange rate for Nigeria and South Africa. Visual inspection of the plot of exchange rate shows that the Naira experienced a constant value between the periods 2013-2014 and January 2015 to the second quarter of 2016. However, the Rand exhibited fluctuating trends sugestive of free floating exchange rate regimes. When differenced to obtain their returns, the trends revealed major swings in the South African Rand while the Nigerian Naira was relatively flat with scanty periods of swings.
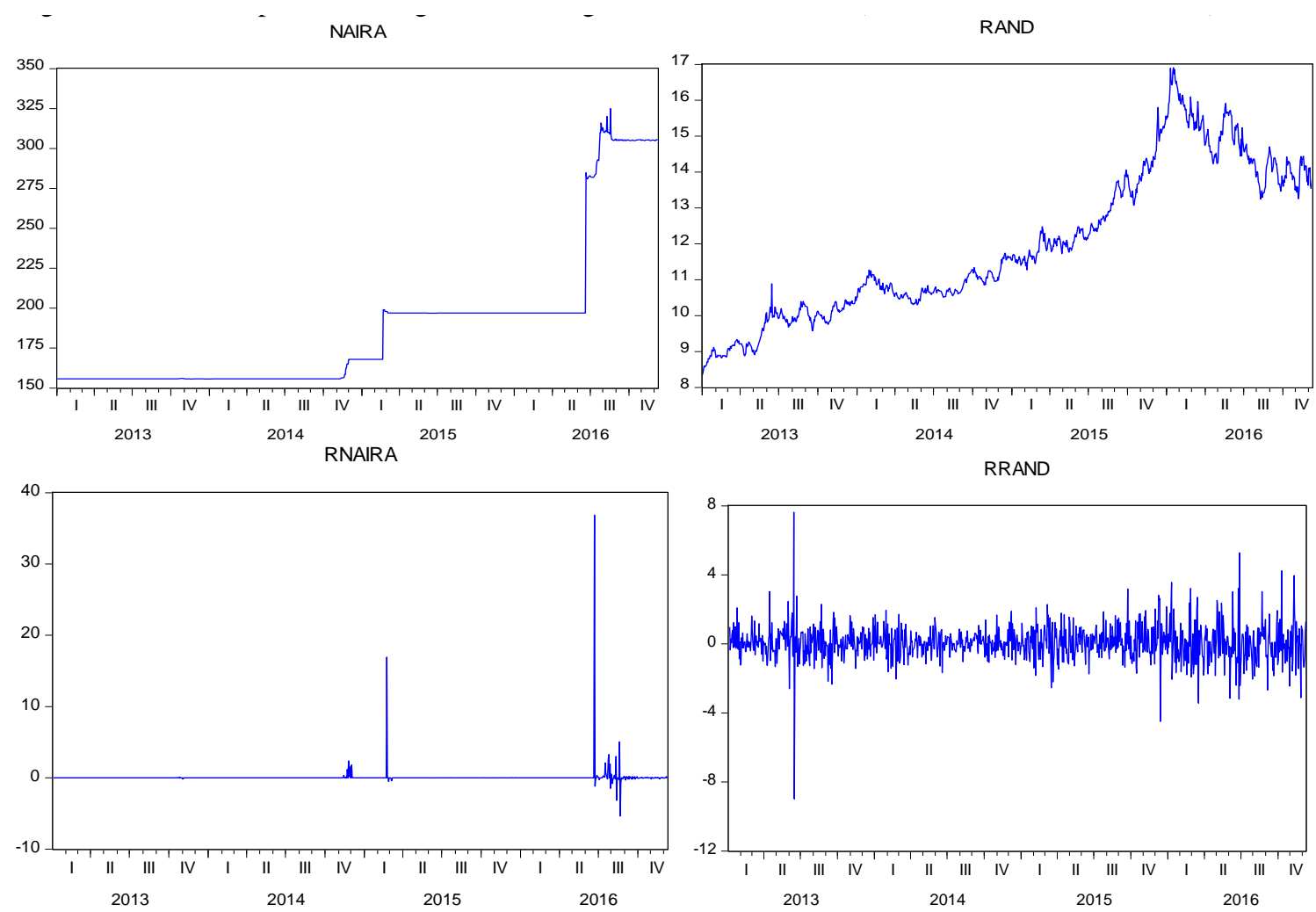

Figure 1. Line graph of exchange rate for Nigeria and South Africa (Level and differenced trend)

Source: CBN and Bloomberg.

Table 2 report the result of Augmented Dickey-Fuller (ADF) unit root tests for the returns of exchange rate, stock market and crude oil price. All their p-values are highly significant at 5\% critical value, thus, the null hypothesis of unit root is rejected affirming that the return series are stationary at level.

Table 2. Unit root tests

\begin{tabular}{llllll}
\hline S/N & Variables & & Trend & Lag & Probability \\
\hline Currency & Naira & Level & -33.3888 & 0 & 0.0000 \\
& Rand & Level & -34.7833 & 0 & 0.0000 \\
Stock Exchange & Nigeria & Level & -21.3005 & 0 & 0.0000 \\
& South Africa & Level & -147087 & 6 & 0.0000 \\
Crude Oil & & Level & -25.2803 & 1 & 0.0000 \\
\hline
\end{tabular}

Note. The AIC is used for selecting the lag length. 


\subsection{Estimated Mean and Variance Equation for Exchange Rate Volatility}

Fitting different Auto Regressive (AR), Moving Average (MA), and ARMA models to the returns by varying the order combinations using Akaike information criterion (AIC) and Schwarz criterion (SIC) gives MA(1) for the expected mean function for the Naira and MA(1) for the Rand. In order to estimate a conditional variance equation for each of the currency, the test for $\mathrm{ARCH}$ effects in the estimated mean equation is conducted to ensure that there is presence of heteroscedasticity as suggested by the skewness, kurtosis and Jarque-Bera statistics as shown in Table 1. Table 3 shows the result of the test for ARCH effect in the residuals of the mean equation for exchange rate returns.

Table 3. Heteroscedasticity test: ARCH effect test

\begin{tabular}{llll}
\hline Lag & Return series & NAIRA & RAND \\
\hline \multirow{2}{*}{ Lag 1 } & F-statistic & 0.0009 & 192.9782 \\
& Probability F-statistics & 0.9751 & 0.0000 \\
& Probability chi-square & 0.9750 & 0.0000 \\
\hline
\end{tabular}

The p-value of the F-statistics and chi-square for Naira are not significant at 5\% level, thus, the null hypothesis of no ARCH cannot be rejected. On the other hand, both the p-value of the Rand is highly significant at $5 \%$ level implying the presence of ARCH effect. The conditional variance of Rand returns can therefore be estimated.

\subsection{Estimation of ARCH/GARCH Models}

The mean and conditional variance of $\operatorname{TGARCH}(4,1)$ model for South Africa is presented in Table 4. Student's- $t$ distribution was used to estimate the TGARCH model based on the AIC and SIC criteria. In the TGARCH model, the ARCH coefficient at lag 1 is significant at $5 \%$ which implies that only the immediate squared lagged error terms has positive and significant impact on the current period volatility. Similarly, the coefficient of the GARCH term is significant, which also implies that previous period volatility does have significant impact on the conditional volatility at the current period.

Table 4. Estimate result of the mean and conditional variance TGARCH (South African rand)

\begin{tabular}{ccccc}
\hline Variable & Coefficient & Std. Error & z-Statistic & Prob. \\
\hline C & 0.048626 & 0.025179 & 1.931217 & 0.0535 \\
MA(1) & 0.021856 & 0.030697 & 0.711997 & 0.4765 \\
\hline Variance Equation \\
C & 0.000647 & 0.001082 & 0.598170 & 0.5497 \\
RESID(-1)^2 & 0.140678 & 0.044546 & 3.158052 & 0.0016 \\
RESID(-1) $2^{*}(\operatorname{RESID}(-1)<0)$ & -0.070182 & 0.015729 & -4.461995 & 0.0000 \\
RESID(-2) 2 & -0.068234 & 0.062467 & -1.092319 & 0.2747 \\
RESID(-3)^2 & 0.038247 & 0.062583 & 0.611139 & 0.5411 \\
RESID(-4)^2 & -0.070307 & 0.047300 & -1.486392 & 0.1372 \\
GARCH(-1) & 0.993611 & 0.003090 & 321.5990 & 0.0000 \\
T-DIST. DOF & 5.947547 & 1.129050 & 5.267746 & 0.0000 \\
\hline
\end{tabular}

The leverage effect coefficient is highly significant at $5 \%$ level, this is an indication of the presence of leverage effect. The non-negativity constrain is satisfied since $\beta_{0}>0, \beta_{i}>0, \alpha_{1} \geq 0$, and $\beta_{i}+\gamma \geq 0$. The sum of the $\mathrm{ARCH}$ and GARCH coefficients indicates that the persistence of volatility will die out very quickly because the value is greater than 1 . Figure 2 indicates that the volatility model fitted captures major periods of high and low Exchange rate returns volatilities rand. 


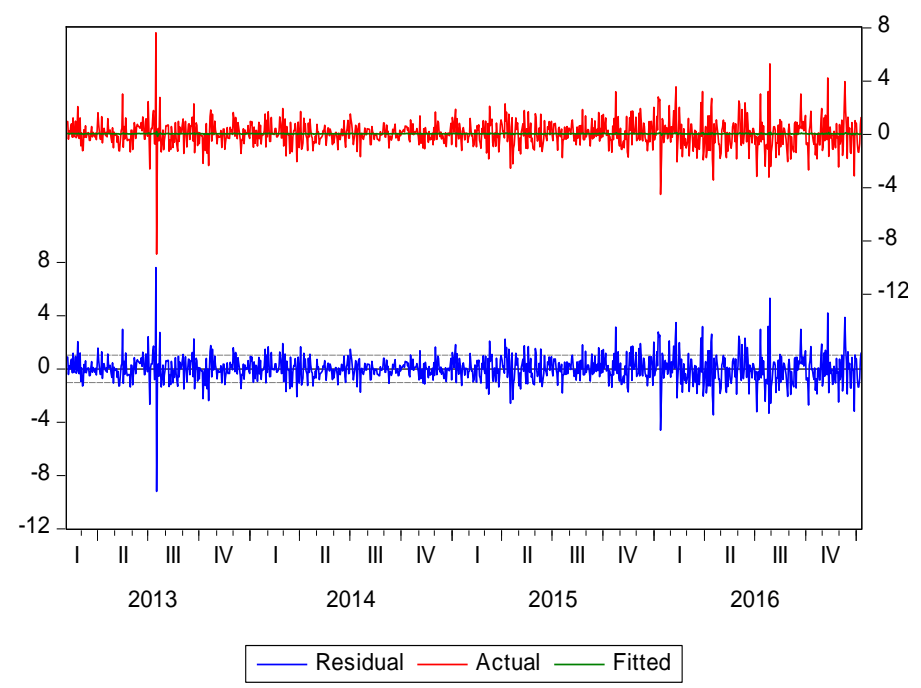

Figure 2. conditional volatilities for fitted TGARCH model for South Africa rand

In order to evaluate the estimated model, a diagnostic test for standardized residuals (Ljung-Box) is required. This is a test for serial correlation in the residuals of the fitted TGARCH $(4,1)$ model presented in Table 5 . The p-value of the chi-square is not significant. Thus, the null hypothesis of no remaining ARCH effect in the model cannot be rejected at 5\% significant level implying that, the serial correlation of standardized residuals have been accounted for.

Table 5. Heteroscedastic test for fitted TGARCH models

\begin{tabular}{lc}
\hline Heteroscedasticity test: ARCH & lag 1 \\
F-statistics & 3.1375 \\
Prob. F(1,286) & 0.0768 \\
Obs*R-squared & 3.1341 \\
Prob. Chi-Square(1) & 0.0767 \\
\hline
\end{tabular}

\subsection{Effect of Exchange Rate and Crude oil on Stock Market}

This section estimates the effect of exchange rate returns and crude oil price on all shaer indices of the Nigerian and Johannesburg stock exchanges. The result for Nigeria shows that exchange rate returns, the previous value of the stock market, the previous value of the Nigerian stock exchange, crude oil price and its previous value, have a positive effect on the performance of the Nigerian stock exchange (see Table 6). The exchange rate return of the Nigerian naira has a coeficent of 0.054 . This implies that a one percentage appreciation in the value of the naira, will increase the all share index of the Nigerian stock exchange by 0.054 percent. The effect of crude oil price returns on the Nigerian stock exchange was also signifcant at $5 \%$ critical value. It showed that a percentage increase in crude oil orice, increases the performance of the Nigerian stock exchange by 0.048 percent. The fact that improvement in the value of the naira have a higher impact on the performance of the Nigerian stock exchange compared to the crude oil price, reiterates the need for the Central Bank of Nigeria to sustain its current effort of intervening in the forex market as a means of stabilizing and improving the value of the countries exchange rate. Nevetheless, policies aimed at diversifying the Nigerian economy, encouraing more non-oil stocks to be quoted in the Nigerian stock exchange, while keeping watch on all forms of insider abuse with regards to oil stocks, will be critical to enhance the performance of the Nigerian stock exchange. 
Table 6. Effect of exchange rate returns and crude oil price on stock market performance

\begin{tabular}{lclc}
\hline Variables & Nigeria & Variables & South Africa \\
\hline & -0.000706 & & 0.0472 \\
Constant & {$[0.9837]$} & Constant & {$[0.3606]$} \\
& $0.054058^{* *}$ & & -0.0678 \\
RNaira & {$[0.0311]$} & RRand & {$[0.1873]$} \\
& 0.021095 & & $0.13204 * * *$ \\
RCrude_Oil & {$[0.1852]$} & RCrude_Oil & {$[0.000]$} \\
& $0.324156^{* * *}$ & & -0.0323 \\
RNSE(-1) & {$[0.000]$} & R-JSE(-1) & {$[0.3106]$} \\
& $0.06258^{* *}$ & & -0.0691 \\
RNaira(-1) & {$[0.0127]$} & RRand (-1) & {$[0.1785]$} \\
& $0.0485^{* * *}$ & & $0.057919^{* *}$ \\
RCrude_Oil(-1) & {$[0.0019]$} & RCrude_Oil(-1) & {$[0.0185]$} \\
R-squared & 0.1326 & R-squared & 0.043 \\
Adjusted R-Squared & 0.1279 & Adjusted R-Squared & 0.0384 \\
F-statistic & 28.02 & F-statistic & 8.785 \\
Prob(F-statistic) & 0.00 & Prob(F-statistic) & 0.00 \\
Durbin-Watson & 2.004 & Durbin-Watson & 2.028 \\
Observations (after adjustment) & 922 & Observations (after adjustment) & 975 \\
\hline
\end{tabular}

Dependent Variable are Stock Market Equities (Nigerian and Johannesburg Stock Exchange).

Note. *** (significant at 1\%), ** (significant at 5\%), * (significant at 10\%).

Figures is square bracket [ ] are probability values.

For South Africa, it was found that the Rand have a negative effect on the performance of the Johannesburg Stock Exchange. Although not statistically significant, it suggests that a one percentage fall in the value of the Rand, drags down the performance of the JSE by 0.07 percent. On the other hand, crude oil was found to have a significant and positive impact on the performance of the JSE. Specifically, a percentage increase in crude oil price, improves the performance of the Johannesburg stock exchange by 0.06 percent. Though not surprising that crude oil price has a significant effect on the JSE, it is worrisome for South Africa that the effect of its exchange rate on the JSE was not significant. Sustaining effort towards strengthen the Rand is therefore important, to sustaining and attract new investments to the South African economy and to minimize the exposure of its capital market investment to external shocks that is associated with commodity prices.

\subsection{VAR Granger Causality Test}

To measure the exposure of the currency movement in specific countries to other currencies and stock market performance, the VAR Granger causality was used. It was found that all the variables (UK FTSE 100, South African JSE, Japanese NIKKEI 225, the NSE, the UK Pounds, South African Rand and Japanese Yen), granger cause the movement in the exchange rate of the Nigerian Naira relative to the US dollar (see Table 7). On the other hand, no causality was found between all the variables and the Nigerian stock market except the naira exchange rate itself. Domestic policies geared towards making the naira stronger and resilient to external shocks is therefore critical.

Table 7. VAR Granger causality for stock market and currency movement: Nigeria

\begin{tabular}{|c|c|c|c|c|c|c|c|}
\hline \multicolumn{4}{|c|}{ Dependent variable: $D$ (NSE) } & \multicolumn{4}{|c|}{ Dependent variable: D(NAIRA) } \\
\hline Excluded & Chi-sq & $\mathrm{df}$ & Prob. & Excluded & Chi-sq & $\mathrm{df}$ & Prob. \\
\hline $\mathrm{D}(\mathrm{FTSE})$ & 1.822629 & 2 & 0.4020 & $\mathrm{D}$ (FTSE) & 5.132991 & 2 & 0.0768 \\
\hline $\mathrm{D}(\mathrm{JSE})$ & 3.788639 & 2 & 0.1504 & D(JSE) & 4.622879 & 2 & 0.0991 \\
\hline D(NAIRA) & 6.975826 & 2 & 0.0306 & D(NIKKEI) & 2.274872 & 2 & 0.3206 \\
\hline $\mathrm{D}(\mathrm{NIKKEI})$ & 0.873992 & 2 & 0.6460 & D(NSE) & 8.059249 & 2 & 0.0178 \\
\hline D(POUND) & 0.151951 & 2 & 0.9268 & D(POUND) & 1.335314 & 2 & 0.5129 \\
\hline D(RAND) & 0.550758 & 2 & 0.7593 & D(RAND) & 2.794260 & 2 & 0.2473 \\
\hline $\mathrm{D}(\mathrm{YEN})$ & 0.716151 & 2 & 0.6990 & $\mathrm{D}(\mathrm{YEN})$ & 3.210141 & 2 & 0.2009 \\
\hline All & 21.04212 & 14 & 0.1006 & All & 31.30102 & 14 & 0.0050 \\
\hline
\end{tabular}

For South Africa, all the variables (UK FTSE 100, South African JSE, Japanese NIKKEI 225, the NSE, the UK 
Pound, Nigerian naira and Japanese Yen), were found to granger cause the South African Rand, while all the variables (UK FTSE 100, Nigerian Naira, Japanese NIKKEI 225, Nigerian Stock market, UK pound, South African Rand and the Japanese Yen), were also found to granger cause the Johannesburg Stock Exchange (see Table 8). It appears that for South Africa, maintaining a policy that minimizes the exposure of its exchange rate and stock market performance will be critical as its level of exposure to external shocks will be more devastating. To minimize exposure of its stock market performance, the VAR granger causality model reveals that keeping watch on the shocks from the UK stock market and maintaining a healthy rand exchange rate will be vital.

Table 8. VAR Granger causality for stock market and currency movement: South Africa

\begin{tabular}{|c|c|c|c|c|c|c|c|}
\hline \multicolumn{4}{|c|}{ Dependent variable: D(JSE) } & \multicolumn{4}{|c|}{ Dependent variable: $\mathrm{D}$ (RAND) } \\
\hline Excluded & Chi-sq & $\mathrm{df}$ & Prob. & Excluded & Chi-sq & $d f$ & Prob. \\
\hline $\mathrm{D}(\mathrm{FTSE})$ & 14.67918 & 2 & 0.0006 & $\mathrm{D}$ (FTSE) & 4.044172 & 2 & 0.1324 \\
\hline D(NAIRA) & 2.846433 & 2 & 0.2409 & $\mathrm{D}(\mathrm{JSE})$ & 0.336445 & 2 & 0.8452 \\
\hline $\mathrm{D}$ (NIKKEI) & 0.654278 & 2 & 0.7210 & D(NAIRA) & 4.706529 & 2 & 0.0951 \\
\hline $\mathrm{D}$ (NSE) & 0.001614 & 2 & 0.9992 & $\mathrm{D}(\mathrm{NIKKEI})$ & 1.147678 & 2 & 0.5634 \\
\hline $\mathrm{D}$ (POUND) & 0.604142 & 2 & 0.7393 & D(NSE) & 2.494604 & 2 & 0.2873 \\
\hline $\mathrm{D}$ (RAND) & 7.205736 & 2 & 0.0272 & $\mathrm{D}$ (POUND) & 3.540186 & 2 & 0.1703 \\
\hline $\mathrm{D}$ (YEN) & 3.324531 & 2 & 0.1897 & $\mathrm{D}$ (YEN) & 7.726091 & 2 & 0.0210 \\
\hline All & 45.42743 & 14 & 0.0000 & All & 27.70519 & 14 & 0.0156 \\
\hline
\end{tabular}

\section{Discussion}

Recent discourse on exchange rate management in developing and emerging countries have focused on whether to float or not to float the exchange rate. Such a perspective, turns the attention of analyst towards examining the direct effect of exchange rate on the economy. Using data on South Africa and Nigeria, this paper examines the exchange rate returns of both countries for the presence of volatility and also examines the effect of the exchange rate returns on the performance of their respective stock markets. The theoretical framework adopted for the paper is the flow oriented hypothesis, which states that movement of a country's exchange rate, leads to movement in asset prices. Because presence of volatility in exchange rate returns could have policy implications, the ARCH/GARCH was used to investigate the presence of volatility clustering in the South African Rand (relative to the US dollar) and the Nigerian Naira (relative to the US dollar). While it was found that the South African Rand was volatile, the Nigerian naira was not. The test for ARCH effects in the estimated mean equation showed that the p-value of the F-statistics and chi-square for the Naira were not significant at 5\% level, thus, the null hypothesis of no ARCH could not be rejected. On the other hand, both the p-value of the Rand was highly significant at 5\% level hence, implying the presence of ARCH effect.

When the effect of exchange rate returns and crude oil price on the stock market indices of both countries was estimated, the result for Nigeria showed that exchange rate return have a positive effect on the performance of the Nigerian stock exchange. Thus, confirming the stock flow hypothesis for Nigeria. On the contrary, though it was found that the Rand returns have a negative effect on the performance of the Johannesburg Stock Exchange, the result was not statistically significant. Thus, failing to validate the stock flow hypothesis for South Africa. The paper concludes that policies aimed at diversifying the Nigerian economy, encouraing more non-oil stocks to be quoted in the Nigerian stock exchange, while keeping watch on all forms of insider abuse with regards to oil stocks, will be critical to enhance the performance of the Nigerian stock exchange. The significance of exhange rate returns in the Nigerian stock exchange and the need to curtail its effect on the Nigerian stock exchange, is consistent with Caporale et al. (2015) who argued that exchange rate or credit controls can be used to improve the flow of investment particularly in countries where high level of uncertainty affects economic and financial system stability. Considering the rapid drop in the Nigerian naira in recent times and the results obtained from this study, the intervention of the CBN which intervenes in the nation's forex through the supply side is justified. For sustainability however, policies seek to encourage the diversification of the Nigerian economy might needful.

For South Africa the findings suggest that since the South African stock market is not really exposed to the negative effects of currency volatility, the weak volatility transmission from the rand to stock market may be indicative of increased use of hedging instruments by firms on the JSE. Hence, more efficient hedging instruments needs to be put in place by firms on the stock market to ensure the elimination of negative effects of rand volatility. This finding is consistent with Mlambo et al. (2013) who examined the effect of currency volatility on the Johannesburg Stock Exchange and found a weak relationship between currency volatility and 
the stock market. Since the South African stock market did not have much exposure to the negative effects of currency volatility, they recommended that the South African government can use exchange rate as a policy tool to attract foreign portfolio investment. As Nieh and Lee, (2001) and Stavárek (2005) argued therefore, understanding the relationship between exchange rate and stock market is important for both Nigeria and South Africa as it will assist domestic and international investors to hedge and diversify their portfolio. At any price, maintaining exchange rate stability is therefore critical for both countries.

From the VAR granger causality model, it was found that the naira has some level of exposure to shocks from external shocks. On the other hand, no causality was found between all the variables and the Nigerian stock market except the naira exchange rate itself. Domestic policies geared towards making the naira stronger and resilient to external shocks is therefore critical. Although South Africa's Rand (relative to the US dollar) also had exposure to external shocks, the same set of variables also had significant short term effect on the Johannesburg Stock Exchange. It appears therefore that for South Africa, maintaining a policy that minimizes the exposure of its exchange rate and stock market performance will be critical as spillover effects on South Africa in the event of external shocks will be more devastating. To minimize exposure of the JSE, our estimation reveals that keeping watch on the shocks from the UK stock market (FTSE 100) and maintaining a healthy rand exchange rate will be crucial.

\section{Summary and Conclusion}

The main objective of this paper is to examine the impact of Exchange rate returns on the stock market in South Africa and Nigeria. The data used span from 2013-2016 and were converted to returns. Application of Jarque-Bera test yielded statistics that affirmed non-normal distribution of all the variables. Stationarity of the all the series was checked with ADF test and the results showed stationarity at level for all the series. The estimations revealed a very weak relationship between exchange rate volatility of rand and the stock market of South Africa implying that, global economic conditions affect the stock market in South Africa. This finding is consistent with Raddatz (2008) who investigated the impact of exchange rate volatility on trade and exports in South Africa and found no evidence that exchange rate volatility affects South African exports or trade flows. More so, that exchange rate volatility has a serious implication on the South Africa stock market. Since exchange rate volatility affects investor's decision, it is therefore of concern as to whether or not floating the exchange rate for a country like Nigeria with weak exports. The investigation of the exchange rate for volatility therefore became paramount. Although the ARCH effect test showed no evidence of volatility - which is consistent with the findings in Mlambo et al. (2013), the result for Nigeria shows that exchange rate returns, the previous value of the stock market, the previous value of the Nigerian stock exchange, crude oil price and its previous value, have a positive effect on the performance of the Nigerian stock exchange. The fact that improvement in the value of the naira have a higher impact on the performance of the Nigerian stock exchange compared to the crude oil price (as also shown in Abraham, 2016), reiterates the need for the Central Bank of Nigeria to sustain its current effort of interveneing in the forex market as a means of stabilizing and improving the value of the countries exchange rate. Policies aimed at diversifying the Nigerian economy, encouraing more non-oil stocks to be quoted in the Nigerian stock exchange, while keeping watch on all forms of insider abuse with regards to oil stocks, will be critical to enhance the performance of the Nigerian stock exchange.

In case of South Africa, it was found that the Rand have a negative effect on the performance of the Johannesburg Stock Exchange. Although this result is consistent with the findings from Barr and Kantor (2003), it was not statistically significant, thus, suggesting that a fall in the value of the Rand, would have a negative effect on the performance of the JSE. Due to weakening position of manufacturing and transport sector in South Africa as argued in UNECA and AU (2013), stocks with exposure to the fluctuation in crude oil prices will therefore, further expose the Johannesburg Stock Exchange to the vagaries of crude oil price fluctuation in the international market. Hence, when examined for South Africa, it was found that crude oil have a significant and positive impact on the performance of the JSE. This finding is consistent with Aphane (2011)

Who found a negative relationship between oil price and the rand dollar exchange rate implying that, the South African rand would suffer from latent depreciation should incase oil price increases. Though not surprising, it is worrisome for South Africa that the effect of its exchange rate on the JSE was not significant. Sustaining effort towards strengthening the Rand is therefore important to retain and attract new investments to the South African economy and to minimize the exposure of its capital market investment to external shocks that is associated with commodity prices. The findings from this study have a number of policy implications. Firstly, as argued in Mlambo et al. (2013), the weak volatility transmission from the rand to stock market may be indicative of increased use of hedging instruments by firms on the JSE. More efficient hedging instruments needs to be put in place by firms on the stock market to ensure the elimination of negative effects of rand volatility. These hedging 
instruments should not distort the normal functioning of the JSE. Secondly, since the South African stock market is not really exposed to the negative effects of currency volatility. Hence, curtailing the frequent swings in the exchange rate of the Rand, could be used as a policy tool to attract foreign portfolio investment.

\section{References}

Abraham, T. W. (2016). Exchange rate policy and falling crude oil prices: Effect on the Nigerian stock Market. CBN Journal of Applied Statistics, 7(1a), 111-123.

Adjasi, C. K. D., \& Biekpe, B. N. (2005). Stock market returns and exchange rate dynamics in selected African countries: A bivariate analysis. In C. Mlambo, A. Maredza, \& K. Sibanda (2013), Effects of Exchange Rate Volatility on the Stock Market: A Case Study of South Africa. Mediterranean Journal of Social Sciences, 4(14), 561-570.

Agrawal, G., Srivastav, A. K., \& Srivastava, A. (2010). A study of exchange rates movement and stock market volatility. International Journal of Business and Management, 5(12), 62-73. https://doi.org/10.5539/ijbm.v5n12p62

Aphane, A. K. (2011). The effect of oil price and currency volatility on the stock price of oil and gas companies in South Africa. A Research Report Presented to the Graduate School of Business Leadership University of South Africa (November).

Barr, G. D. I., \& Kantor, B. S. (2003). The Impact of the Rand on the Value of the Jonesburg Stock Exchange. Retrieved from http://www.zaeconomist.com/research/2003.pdf

Benita, G., \& Lauterbach, B. (2004). Policy Factors and Exchange Rate Volatility: Panel Data Verses a Specific Country Analysis. Research Unit, Foreign Exchange Activity Department, Bank of Israel, Jerusalem.

Bollerslev, T. (1986). Generalised Autoregressive Conditional Heteroscedasticity. Journal of Econometrics, 31, 307-327. https://doi.org/10.1016/0304-4076(86)90063-1

Branson, W. H. (1983). Macroeconomic determinants of real exchange rates. In Herring, R. J. (Ed.), Managing Foreign Exchange Risk. Cambridge University Press.

Caporale, G. M., Ali, F. M., \& Spagnolo, N. (2015). Exchange rate uncertainty and international portfolio flows: A multivariate GARCH-in-mean Approach. Journal of International Money and Finance, 54, 70-92. http://dx.doi.org/10.1016/j.jimonfin.2015.02.020

Ding, Z., Granger, C. W. J., \& Engle, R. F. (1993). A Long Memory property of Stock Market Returns and a New Model. Journal of Empirical Finance, 1, 83-106. https://doi.org/10.1016/0927-5398(93)90006-D

Dornbusch, R., \& Fischer, S. (1980). Exchange Rates and the Current Account. The American Economic Review, 70(5), 960-971.

Engle, R. F. (1982). Autoregressive Conditional Heteroscedasticity with estimates of the Variance of the United Kingdom Inflation. Econometrics, 50, 987-1008. https://doi.org/10.2307/1912773

Fama, E. F., \& French, K. R. (2004). The Capital Asset Pricing Model: Theory and Evidence. Journal of Economic Perspectives, 18(3), 25-46. https://doi.org/10.1257/0895330042162430

Gatawa, N. M., \& Mahmud, A. A. (2017). Impact of exchange rate fluctuations on agricultural exports (crops) in Nigeria. International Journal of Humanities and Social Science Invention, 6(3), 65-71.

Gavin, M. (1989). The stock market and exchange rate dynamics. Journal of International Money and Finance, 8, 181-200. https://doi.org/10.1016/0261-5606(89)90022-3

Grubel, H. G. (1968). Internationally diversified portfolios: Welfare gains and capital flows. American Economic Review, (December), 1299-1314.

Joseph, N. (2002). Modelling the impacts of interest rate and exchange rate changes on UK Stock Returns. Derivatives Use, Trading \& Regulation, 7(4), 306-323.

Kim, K. (2003). Dollar exchange rate and stock price: Evidence from multivariate cointegration and error $\begin{array}{lllll}\text { correction model. Review of Financial Economics, } & 12, & \text { 301-313. }\end{array}$ https://doi.org/10.1016/S1058-3300(03)00026-0

Kuroda, H. (2014). The Practice and theory of unconventional monetary policy. Speech at the 17th World Congress Hosted by the International Economic Association (IEA) Held in Jordan

Lintner, J. (1965). The valuation of risk assets and the selection of risky investments in stock portfolios and 
capital budgets. Review of Economics and Statistics, 47(1), 13-37. https://doi.org/10.2307/1924119

Malkiel, B. G., \& Fama, E. F. (1970). Efficient capital markets: A review of theory and empirical work. The Journal of Finance, 25(2), 383-417. https://doi.org/10.1111/j.1540-6261.1970.tb00518.x

Mishra, A. K., Swain, N., \& Malhotra, D. (2007). Volatility spillover between stock and foreign exchange markets: Indian evidence. International Journal of Business, 12(3), 343-359.

Mlambo, C., Maredza, A., \& Sibanda, K. (2013). Effects of exchange rate volatility on the stock market: A case study of South Africa. Mediterranean Journal of Social Sciences, 4(14), 561-570. https://doi.org/10.5901/mjss.2013.v4n14p561

Nelson, D. (1991). Conditional heteroscedasticity in asset returns: A new approach. Econometrica, 59(2), 347-370. https://doi.org/10.2307/2938260

Nieh, C. C., \& Lee, C. F. (2001). Dynamic relationship between stock prices and exchange rates for G-7 countries. The Quarterly Review of Economics and Finance, 41, 477-490. https://doi.org/10.1016/S1062-9769(01)00085-0

Ozhan, G. K., Atiyas, I., \& Keyman, E. F. (2016). Unconventional monetary policy and its reflections on the global economy. Think Tank 20: The G-20 and Central Banks in the New World of Unconventional Monetary Policy, pp. 81-87.

Papaioannou, M. (2006). Exchange rate risk measurement and management: Issues and approaches for Firms. IMF Working Paper WP/06/255 (November). https://doi.org/10.5089/9781451865158.001

Phylaktis, K., \& Ravazzolo, F. (2005). Stock prices and exchange rate dynamics. Journal of International Money and Finance, 24, 1031-1053. https://doi.org/10.1016/j.jimonfin.2005.08.001

Raddatz, C. (2008). Exchange rate volatility and trade In South Africa. World Bank Publication. Retrieved from http://siteresources.worldbank.org/DEC/Resources/ExchangeRateVolatiltyTradeSouthAfrica060708Final.pd $\mathrm{f}$

Sharpe, W. F. (1964). Capital asset prices: A theory of market equilibrium under conditions of risk. Journal of Finance, 19(3), 425-442.

Sichoongwe, K. (2016). Effects of exchange rate Volatility on the Stock Market: The Zambian Experience. Journal of Economics and Sustainable Development, 7(4), 114-119.

Stavárek, D. (2005). Stock prices and exchange rates in the EU and the USA: Evidence of their mutual interactions. Finance a úvûr-Czech Journal of Economics and Finance, 55, 141-161.

Thomson, R. J., Şahin, Ş., \& Reddy, T. L. (2013). How a single-factor CAPM works in a multi-currency world. Retrieved from https://www.actuaries.org/lyon2013/papers/AFIR_Thomson_Sahin_Reddy.pdf

UNECA \& AU. (2013). Making the Most of Africa's Commodities: Industrializing for Growth, Jobs and Economic Transformation. United Nations Economic Commission for Africa (UNECA) and African Union $(A U) \quad$ Report. Retrieved from https://www.uneca.org/sites/default/files/PublicationFiles/unera_report_eng_final_web.pdf

Zakoian, J. M. (1994). Threshold heteroscedastic models. Journal of Economic Dynamics and Control, 18, 931-955. https://doi.org/10.1016/0165-1889(94)90039-6

Zhang, Y. (2016). Exploring the relationship between stock prices and exchange rates in North America and China. A Report Submitted Graduate Academic Unit of Economics, University of New Brunswick.

\section{Copyrights}

Copyright for this article is retained by the author(s), with first publication rights granted to the journal.

This is an open-access article distributed under the terms and conditions of the Creative Commons Attribution license (http://creativecommons.org/licenses/by/4.0/). 